
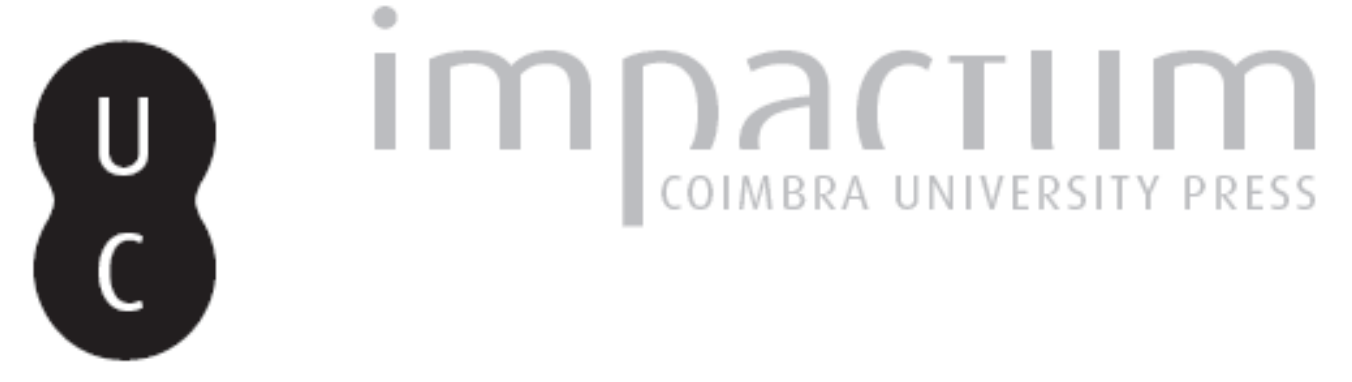

\title{
Characterization through animals: the case of Plutarch's Artaxerxes: part I
}

\section{Autor(es): Almagor, Eran}

Publicado por: International Plutarch Society

URL persistente:

URI:http://hdl.handle.net/10316.2/36373

DOI:

DOI:http://dx.doi.org/10.14195/0258-655X_7_1

Accessed : $\quad$ 26-Apr-2023 15:57:05

A navegação consulta e descarregamento dos títulos inseridos nas Bibliotecas Digitais UC Digitalis, UC Pombalina e UC Impactum, pressupõem a aceitação plena e sem reservas dos Termos e Condições de Uso destas Bibliotecas Digitais, disponíveis em https://digitalis.uc.pt/pt-pt/termos.

Conforme exposto nos referidos Termos e Condições de Uso, o descarregamento de títulos de acesso restrito requer uma licença válida de autorização devendo o utilizador aceder ao(s) documento(s) a partir de um endereço de IP da instituição detentora da supramencionada licença.

Ao utilizador é apenas permitido o descarregamento para uso pessoal, pelo que o emprego do(s) título(s) descarregado(s) para outro fim, designadamente comercial, carece de autorização do respetivo autor ou editor da obra.

Na medida em que todas as obras da UC Digitalis se encontram protegidas pelo Código do Direito de Autor e Direitos Conexos e demais legislação aplicável, toda a cópia, parcial ou total, deste documento, nos casos em que é legalmente admitida, deverá conter ou fazer-se acompanhar por este aviso.

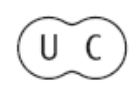




\section{PLOUTARCHOS, n.s.}

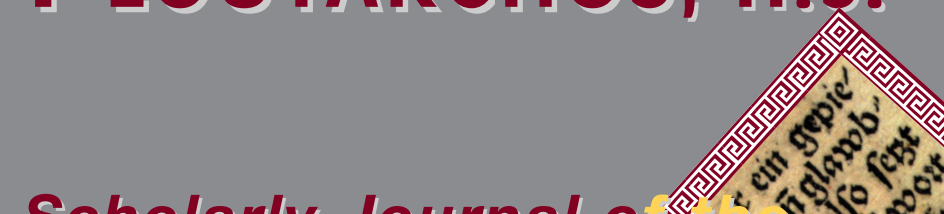

\section{Scholarly Journal o}

International Plut
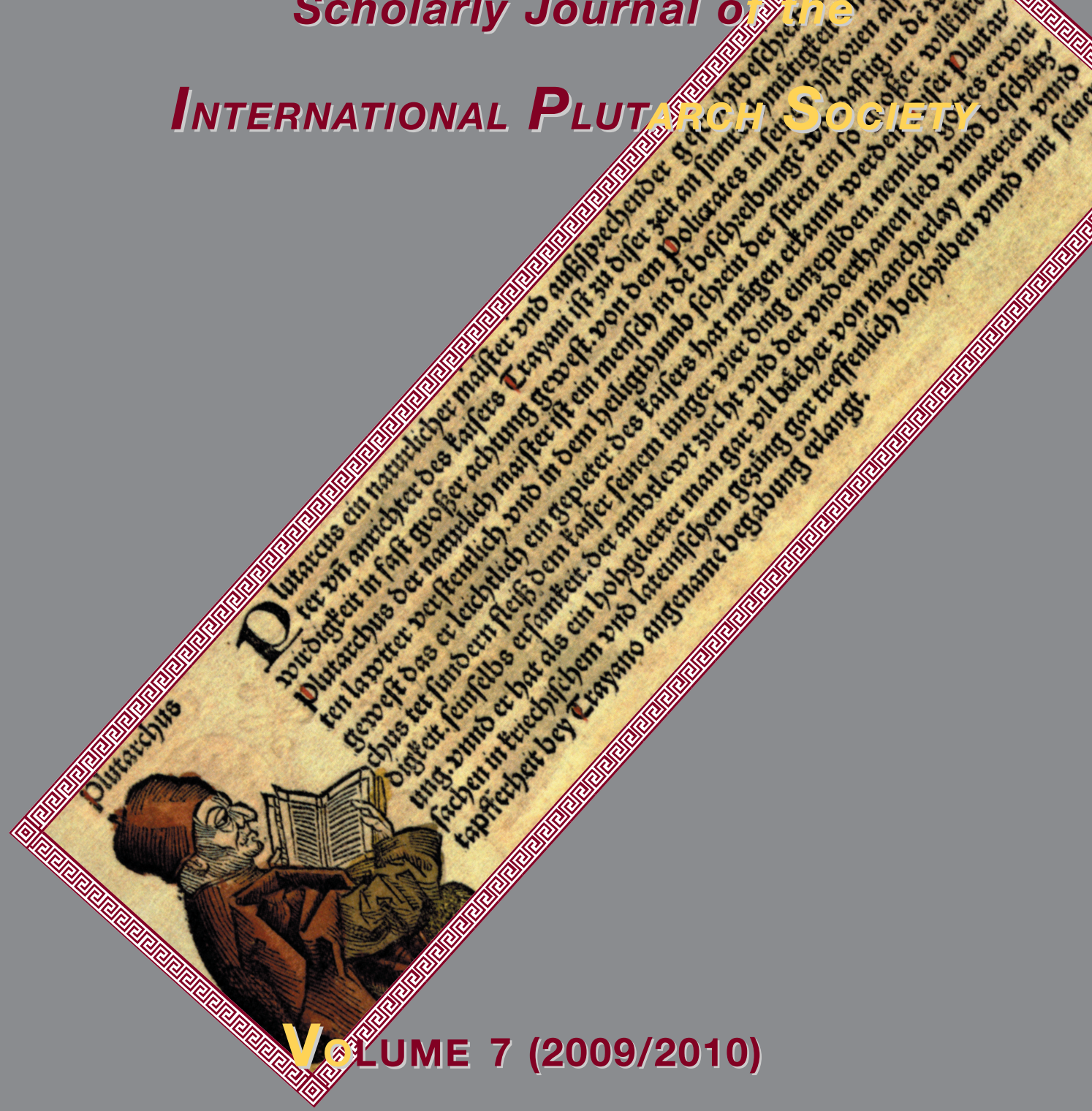

UNIVERSITY OF MÁLAGA (SPAIN) Utah State University, Logan, Utah (U.S.A.) 


\title{
Characterization Through Animals: The Case of Plutarch's Artaxerxes: Part I* \\ by \\ Eran Almagor \\ The Hebrew University of Jerusalem \\ eranalmagor@gmail.com
}

\begin{abstract}
This paper is the first part of three dealing with the subject of characterization through animals in Plutarch's Lives. It argues that beasts have important narratological significance in the biographies, namely, to shed light on the character of the hero through their association with the realm of passions within the human soul. The text chosen to demonstrate this claim is Plutarch's most neglected biography, the Life of the Persian king Artaxerxes.
\end{abstract}

Key-Words: Plutarch's Artaxerxes, Animals, Literary characterization, Platonism.

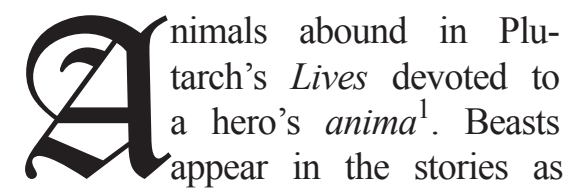

the substance used for the nourishment of men, and as the material for the production of garments ${ }^{2}$. Mention is made of beasts of burden, which are utilized

* I am grateful to Prof. C. Pelling and Dr. T. Whitmarsh for their comments on earlier versions of this paper.

1 A scholarly overview of the literary function of animals in Plutarch is still missing. FunRmanN, 1964: 58-9, 94-100 lists several images of beasts found in his writings. The second section in Boulogne, 2005, entitled 'Animaux et Littérature', is dedicated to literary aspects of certain works. Specific treatments are found in DE LACY, 1952: 169; Brenk, 1987; Mossman, 1988: 86; Duff, 1999: 78-9, 85, 174-176, 191-192, 219, 231, 235; Whitmarsh, 2002: 180-181; Pelling, 2002: 386 n. 71; SAid, 2004: 18-21.

2 Nourishment: Lyc. 12.2; Cor. 3.4; Pomp. 2.6; Luc. 40.2; Ant. 17.6. Garments: Lys. 7.4; Crass. 23.8. 
for the transportation of people and goods ${ }^{3}$. Some animals are manifested in descriptions of battles, in depictions of hunts, and as part of religious ceremonies, where they are either sacrificed to the gods, or used as omens and in prophecy ${ }^{4}$. Certain creatures are introduced as being kept solely as symbols of power and status, as pets, or for entertainment ${ }^{5}$. Wild or tame, living or dead, used as metaphors and similies, or described in lengthy digressions, the presence of animals in the biographies is strongly felt ${ }^{6}$.

This paper, the first part of three dealing with this subject in Ploutarchos, aims to show that all the living creatures mentioned by the Chaeronean are not included in the text simply in order to make the Lives livelier, but have important narratological significance. In particular, it is claimed here that beasts are incorporated in the biographies with the intention of characterizing the nature of each hero, portray its complex relation with nurture in moulding character, and even suggest the possibility of a change in it $^{7}$. The seemingly random assortment of anecdotes and straightforward details involving animals are in fact laden with meanings and also indicate Plutarch's views on the relation of beasts and human beings. The biography chosen to explore these references to animals is that of the Persian king Artaxerxes, which is probably the most neglected Life of Plutarch ${ }^{8}$. This work is relevant
3

4

Battles: Alex. 33.8; Demet. 28.6; Pyr. 17.6, 21.7, 25.6, 27.5. Hunts: Pomp. 12.5; Tim. 22.5; Demet. 3.2, 50.9. Sacrifice: Thes. 4.1, 18.3; Rom. 21.10; Sol. 23.3; Ages. 17.3, 33.4; Luc. 10.1, 24.5-6. Omens and prophecy: Sul. 27.2-5; Rom. 9.5-7; Tib. Grac. 17.3; Alex. 73.4, Ages. 9.5, Pyrrh. 30.5, Cim. 18.5; Arat. 43.6.

Power and status: Sert. 11.7-8; Pub. 19.4; Luc. 39.3. Pets: Per. 1.1; Alc. 9.1-2; Them. 10.9-10. Entertainment: Sul. 5.1; Lyc. 20.6.

6 Dead animals: Alex. 61.1-3; Cat. Mai. 5.3-4. Metaphors and similes: Demos. 23.5-6; Luc. 39.4; Ages. 36.5; Them. 29.2. Digressions: Pomp. 25.7; Flam. 10.6.

7 See Russell, 1966: 146; Bucher-IsLer, 1972: 79-80, for the opinion that Plutarch believes in the constant nature (physis) of a hero, i.e., his inborn qualities, as opposed to his changeable character. Cf. De tranq. an., 475d-476a; De sera 551d, 562b. Yet cf. GiLl, 2006: 412-21.

8 It rarely appears in discussions dealing with Plutarch's aims, methods and literary techniques. Till recently, the only extant commentaries were the short ones of FLACELIĖRE \& Chambry, 1977, Manfredini, Orsi \& Antelami, $1987: 267-308$ and of Marasco, 1994: 657-670, none of them comprehensive and none treating the literary side. C. BINDER's Plutarchs Vita des Artaxerxes: Ein historischer Kommentar (Berlin, 2008) does not radically change the picture, as it is essentially a historical commentary. Other studies examine specific issues, such as Quellenforschung. See M. Haug, Die Quellen Plutarchs 
to the issue in that it centres around a barbarian hero, who is, almost by (Greek) definition, a human being closest to brutes ${ }^{9}$, notwithstanding the fact that Persians are also typically known to be effeminately civilized and culturally over-refined ${ }^{10}$.

\section{Animals and the Hero}

Just as the inclusion of minor characters in Plutarch's Lives may be ascribed not solely to their presence in the original source material at the biographer's disposal, but also to their literary function in the narrative ${ }^{11}$, so is the use of animals in the biographies. In the same way as each and every figure in the Lives can be considered representing different traits of the hero's nature ${ }^{12}$, diverse beasts could be regarded as used by Plutarch in order to

in den Lebensbeschreibungen der Griechen (Tuebingen, 1854), 87-98; ScноттіN, Observationes de Plutarchi Vita Artaxerxis, (Budissin, 1865); C. F. SMith, A Study of Plutarch's Life of Artarxerxes, (Leipzig, PhD diss, 1881); O. A. MANTEY, Welchen Quellen folgte Plutarch in seinem Leben des Artaxerxes, (Greifenberg in Pommern, 1888); P. KRumbHolz, De Ctesia Aliisque Auctoribus in Plutarchi Artaxerxis Vita Adhibitis (Eisenach, 1889); D. C. Hood, Plutarch and the Persians, (PhD Diss. Univ. of South Calif., 1967) 68-85; J. BuckLer, "Plutarch and the Fate of Antalcidas" GRBS, 18 (1977) 139-145; R. B. Stevenson, Persica, Scottish Academic Press, (Edinburgh, 1997) 24-29; SснмIDT, 1999: 315-324.

9 Arist. EN 7.1145a.29-31, 1149a.10-12; Prob. 909a; cf. Polit. 1.1253a. Cf. the supposed advice of Aristotle to Alexander to treat barbarians as animals and plants (Plut. De fort. Alex. 329b-d); cf. his notions of natural slaves, who should be domesticated as animals: Arist. Polit. 1.1254a15ff. As a rhetorical theme: cf. Strab. 3.3.8, 5.2.7; Josephus, BJ, 2.16.4 (377); Vell. Pat. 2.117.3; Amm. Marc. 16.5.17, 24.8.1; cf. Lib. Or. 15.25, 19.3. Cf. Hall, 1989: 126; IsAac, 2004: 196-207. People dwelling at the marginal zones of the inhabited world are often envisioned as imaginary creatures and not as human. Cf. NIPPEL, 2002: 282-3. Cf. Hdt. 4.105.2; Tac. Germ. 46.4. Cf. Wiedemann, 1986. On this theme in Plutarch, cf. Sert. 14.1; Aem. Paul. 20.4; Mar. 16.2, 20.2, 46.1. Cf. Sснмid, 1999: 29-35. 694d-96a; Arr. Anab. 2.7.4-5; Plut. Ages. 9.5; Hall, 1989: 127-28; IsAac, 2004: 285- 303, 307-8 + figures 2-4 of Attic vase painting.

11 As, e.g., bringing to light the qualities of the subject of the Life. Cf. ZADOROJNYI, 2006, esp. 264, 285; cf. Pelling, 1979: 77-79; 1980: 131, 133, 138; 1988: 140, 293, 310; 2002: 294; StAdTer, 1996: 301-2; DufF, 1999: 135-36, 161, 168-76, 251-2.

12 For instance, in the Artaxerxes several characters throw into relief the milder side of the Great King's ethos, namely, Artaxerxes I (1.1) and his son Ariaspes (30.2). Conversely, the cruel aspect of his soul is embodied in the figures of Parysatis $(6.8,14.9-10)$ and Artaxerxes' son Ochus (30.9). The king's ambition and pursuit of honour are exemplified in Cyrus (6.1) and Ctesias (13.7). Artaxerxes' hesitancy is brought out by Clearchus (8.38 ) and the executioner (29.9) and so forth. 
ultimately highlight various aspects of the main character's psyche $e^{13}$.

At the basis of this suggestion is the assumption that animals are linked by Plutarch with the realm of passions and emotions within the soul ${ }^{14}$. This association evokes the picture of the beast within the human depicted in Plato's psychological imagery (Rep. $9.588 \mathrm{e}-591 \mathrm{~d})^{15}$. Indeed, the correlation of animals and living creatures with the irrational side of its hero assumes an internal division of the human psyche, which is quite compatible with the
Platonic conflict between reason and desire $^{16}$, to which Plutarch adhered ${ }^{17}$. This correspondence is true, even if it does not strictly require postulating Plato's tripartite division of the soul ${ }^{18}$. In conformity with this latter scheme ${ }^{19}$, the soul is portrayed as divided into the rational part ("the calculative",

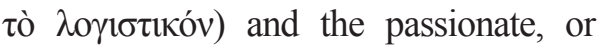
irrational one, which, in turn, is split between the spirited ( $\tau$ ò $\theta 0 \mu \mathrm{o} \varepsilon \delta \delta \varepsilon$ ) and the appetitive ( criterion of division is the respective objects of each element. The spirited part

13 Cases where this link is ostensible and obvious are - to name but a few: Lys. 7.6 (with DuFf, 1999: 174-76); Sul. 28.3; Demos. 23.5-6; Alc. 2.3, 16.3, 23.4-5; Per. 3.3; Arat. 10.4, 30.8; cf. Cleom. 33.8 [54.8], 36.4 [57.4]; Pomp. 28.3.

14 See the allusion to the "animals of the passions" ( $\tau \grave{\alpha} \tau \tilde{\omega} \nu \pi \alpha \theta \tilde{\omega} \nu \theta \rho \varepsilon ́ \mu \mu \alpha \tau \alpha$ ) which have to work with reason (De virt. moral. 451de)

15 This image may even go back to Homer (cf. Od. 20.14-16). In Plato, the lower nature is like a wild beast ( $\theta \rho \varepsilon ́ \mu \mu \alpha$ óypıv: Tim. 70e) that is kept chained up or tamed and trained to obedience (Rep. 9.589ab and also 4.439b, 4.440d), but set loose during sleep (Rep. 9.571c.). Cf. Phaedr. 230a and the horse imagery in 246a ff. and 253c ff., on which cf. also Posidonius, F 31 KIDD-EdelsteIn. One part (the spirited element) is specifically associated with animals: cf. Rep. 4.415e-416c, 441ab. The metaphor was popular among later schools and sects. Cf. Gilhus, 2006: 206-212. It is also found in Aristotle, Polit.

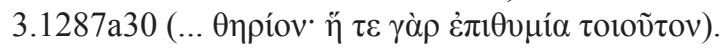

16 Plat. Rep. 4.439c-d. Cf. Tim. 69d.

17 See De virt. moral. 441d-42c; Cf. Plat. Quaest. 1008e. For Platonic influence on Plutarch's understanding of the human soul see Jones, 1916; DufF, 1999: 72-94. Cf. Dillon, 1977: 194.

Plutarch tends to group the irrational elements into one party within a seemingly bipartition division of the soul, in accordance with Peripatetic and Middle-Platonist practices. See REes, 1957; VANDER WAERDT, 1985; 1987. For examples of the conflict between reason and passion in the Lives, see DufF, 1999: 78-82.

19 The tripartite division of the soul is expounded in Plat. Rep. 4.439e-440d, 442a-c; $443 \mathrm{~d}$. Cf. 10.602c-606d; Leg. 1.644e-645c; Tim. 42a-44c, 69b-72d; Phaedr. 246a-249d, 253c-254e, 255e-256d. Cf. Ostenfeld, 1992; Miller, 1999; Gerson, 2003: 99-147; Lorenz, 2006: 14-52; 2008; FERRARI, 2007. Cf. the contrary view of the simplicity and indivisibility of the soul in Phaed. 78c-80b. 
aims for honour and success and has to do with jealousy, ambition, anger and shame; the appetitive strives to attain bodily pleasures (like eating, drinking and reproduction, as well as money and profit $)^{20}$; the rational part has wisdom and truth as its goals. Reason, in keeping with this doctrine, should guide the irrational, lest the emotions get out of control and become harmful ${ }^{21}$. As can be gleaned from Plutarch's writings, the extent to which the rational part of the soul succeeds in controlling passions and repressing desires or fails to do so constitutes the character $(\tilde{\eta} \theta \mathrm{o} \varsigma)$ of a hero 22 and turns it into a virtuous or bad one, respectively ${ }^{23}$. Consequently, excellent education $(\pi \alpha 1-$ $\left.\delta \varepsilon^{\prime} \alpha\right)$ and nurture are significant, in the Chaeronean's thought, for the formation of one's character, as they train the irrational part to be subservient to reason ${ }^{24}$. As incentive to action, passions are mandatory for the exercise of virtue, but the rational part should keep them tamed and within bounds ${ }^{25}$.

The conjecture that animals symbolically stand for emotions in the Lives does not necessarily imply that Plutarch denies animals reason. Quite the contrary can be seen in the Moralia ${ }^{26}$. It

20 Rep. 4.436ab, 4.439c-e, 440a, 442ab; 9.581ab.

21 See Plut. De virt. moral., 441d-443d. Cf. Dillon, 1977: 194; Duff, 1999: 72-76. Cf. Plat. Rep. 4.441e-442b, 444de.

22 See Plut. De virt. moral., 443cd.

23 One should also note a Peripatetic imprint on Plutarch's ethical theory (cf. Dillon,

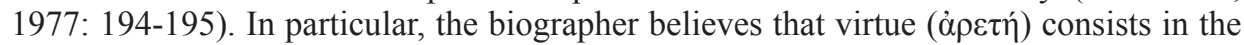
attainment of the right "mean" between two extreme passions (Plut. De virt. moral., 444c-445a, 451de). Aristotle's doctrine of the mean (Arist. NE, 1103a17-18, 1106a23-4, $1106 \mathrm{~b} 35 \mathrm{ff}$.) stresses the habitual choice of the right action, which creates a permanent disposition ( $\check{\xi} \xi \varsigma)$, whereby the passions are continuously restrained (cf. Plat. Leg. 792e). Cf. Plut. De virt. moral. 443d; De cohib. ira 453e-454a; cf. De Garrul. 511e.

24 Plut. De virt. moral., 451b-452d. Cf. SwaIn, 1989: 63, 65; 1990.; DufF, 1999: 76-77; Pelling, 2002: 301-347. Cf. the corresponding emphasis on education in Plato's works: Rep. 4.441e-444a; 8.548b-c; 549ab; 10.606a.

25 Cf. De virt. moral., 449f, 451d. Bearing in mind the triadic hierarchy of god, man and animal (Arist. Polit. 2.1253a26-29; cf. Tatian, Or. ad Graec., 25. Cf. Hes. Th. 535-616; Op. 42-105; Gilhus, 2006: 114-137), and human position as mid-way between deities and beasts (cf. Vernant, 1980; Detienne, 1981), it would seem that the control exercised by rationality over passion links with its figuring as the 'divine' element within us. Accordingly, the suppression of emotions within the soul could also be seen as working in the same way in which man controls the subordinate class of animals in order to articulate his relations to the upper group of gods.

26 Indeed, see the examples assembled in his De Sollertia animalium to prove animal rationality, and the statements in 960a, d, 961d, 962c, 966b, voiced by Autobulus, held to 
is here suggested that for literary ends Plutarch adopts a common stereotype of beasts that is also favoured by several philosophers (especially the Stoics) ${ }^{27}$ - but which does not inevitably express his own views - and employs it in his biographies. The approach set forward in this paper may thus have two advantages for an improved understanding of the working of the Lives. The inclusion of certain details and various digressions in the narratives, rather than merely displaying erudition and the wideranging interests of Plutarch, may be interpreted as intended to shed further light on the hero's character. In similar vein, the apparent contradictions between the attitudes of Plutarch in the Lives and the Moralia in terms of both ideas and tone might be bridged. The inconsistencies should not be consigned to sheer carelessness on Plutarch's part, who slavishly echoes his sources, but could more accurately be explained by assuming his sophistication. Plutarch may be playing with conventional stereotypes and beliefs and with the consequences of his own views concerning animals and other matters ${ }^{28}$, manoeuvring each to highlight different sides of the protagonist. In order to better appreciate the value of the Lives, the reader should postulate that the elements are included by design, and that their aim is to characterize the main figure. Indeed, animal imagery ought to be regarded as one of the organizing principles of the biographies, demonstrating the remarkable artistic coherence and unity of these works.

Plutarch may portray the hero through animals either directly - as part of a narrator's intrusion - or indirectly, as part of the narrative. The

be Plutarch's father. cf. 969c, 985c; Brut. anim. 991f-992c; De esu 997e. Animals share in intellect, though not possessing the same level of reasoning powers that humans have (De sollert. 962c, 963b; cf. De am. prol. 493e). See Newmyer, 1999: 105-7; 2006: 30-47. Cf. Duff, 1999: 246; Gilhus, 2006: 44-52.

27 Cf. Chrysippus, SVF II.826 (= Aetius, Placit., 4.21); Porphyr. De abstin. 3.2; Diog. Laert. 7.51, 55; Sext. Emp. Adv. math. 8.275-6. Cf. Plut. Brut. anim. 992c. See SorabJi, 1993: 21-28, 42; NewMYer, 1999: 102-105; 2006: 26-28, 34-36, 44, 46; Ju, 2007.

28 For example, in the Lives Plutarch does not seem to be strongly opposed to the idea of spontaneous creation of living beings out of inanimate matter (autogenesis). See the description of Sulla's disease (Sul. 36.3), which corrupted his entire flesh, and converted it into worms. Cf. Cleom. 39.5 [60.5], where the wiser men among the Alexandrians are quoted as saying that "as putrefying oxen breed bees, and horses wasps, and as beetles are generated in asses which are in the like condition of decay, so human bodies, when the juices about the marrow collect together and coagulate, produce serpents" (trans. Perrin in the Loeb edition). These passages do not necessarily indicate the opinion of the biographer. In the Moralia he seems to ridicule this idea, especially in relation to the suggestion that rain creates snails instead of merely bringing them out into the open (Quaest. conv. 664c). 
first mode may be seen as Direct Characterization as Animals, employed in a metaphor or a simile involving living creatures. In another mode, the significance beasts carry with relation to the hero's nature is shown rather than told by the narrator, in what may be termed as Indirect Characterization through Interaction with Animals. This interaction may be regarded as a symbol of the internal conflict in the psyche between uncontrolled passion and curtailing reason.

\section{The Invisible Lion}

The first allusion to a beast in the Artaxerxes is to a creature which is not explicitly mentioned in the text. It is a scene of a hunt (5.3), in which the Persian courtier Tiribazus points out to
Artaxerxes that his coat is rent ${ }^{29}$. From the description it is clear that the monarch was still wearing the garment while it was slit. One possibility is that the coat was torn during the hunt by the beast. There is a strong probability that the game alluded to is the $\operatorname{lion}^{30}$. The Achaemenid Kings, following in the footsteps of Near Eastern rulers ${ }^{31}$, are known to chase this animal in their gardens ${ }^{32}$, and the bravery shown by the monarch in this activity formed a part of the royal ideology and propaganda ${ }^{33}$. Indeed, it may be that due to this privilege sport of the kings to hunt the lion, this animal gradually came to be associated in the East with regal power and authority.

It seems surprising, therefore, that the lion does not appear here. This absence,

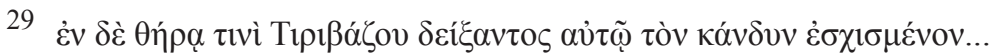

In a passage from another author (Diod. Sic. 15.10.3), Tiribazus tells his judges that once in a hunt he had saved Artaxerxes' life by killing lions which charged upon the king.

31 The royal chase was a symbolic remnant of one of the ancient duties of the leader to organize hunting expeditions against threatening predators and protect the community. The earliest largest stele known from Mesopotamia, dated to the fourth millennium BC portrays the priest-king of Uruk as two figures, one shooting an arrow and another throwing a spear at four lions. The figure of a king struggling with a lion was the theme of Assyrian royal reliefs from the ninth century BC onwards. Well known Assyrian examples are the royal hunt reliefs of Ashurnasirpal II (875-860 BC) from Nimrud and of Ashurbanipal (668-631 BC) from Nineveh, both now in the British Museum. Cf. Albenda, 1972.

32 Cf. BRIANT, 1991; 2002: 231-32, 297-99. The king usually smote the game on horseback (Xen. Anab. 1.2.7; cf. Strab. 15.3.18) or in a chariot. The hunt was performed in open spaces or closed grounds (cf. Xen. Cyr. 1.4.5-15; Curt. Ruf. 8.1.11-12).

33 While the motif of a hunt in the Persian royal ideology is missing from the inscriptions or the reliefs on palace walls (cf. BRIANT, 2002: 209-10), on numerous seals there is an image of a combat of the "royal hero" with lions and fantastic beasts. Of note is a royal seal of Darius I aided by Ahura Mazda, in a chase against a charging lion. See Examples in Briant, 1991: 217-22., 245-46; 2002: 914, 921. Cf. Xen. Cyr. 4.6.3-4. 
however, is entirely consistent with the context of the scene and the mood of chapter 5 of the Artaxerxes, where the king is presented as oblivious to the dangers surrounding him. He treats an insolent Spartan mildly (5.2), does not chastise Tiribazus for being disobedient (5.3-4) and does not recognize the potential danger of his mother (5.5), yet all these groups or persons will sooner or later try to harm him. Moreover, much like the lion in the hunt, the king's brother Cyrus the Younger, who in the meantime assembles a great army (4.3), is conspicuously absent in the chapter ${ }^{34}$, and so the missing beast may symbolically stand for the nonexistent prince. Besides the ostensible implication on the king's character as a person not fully aware of an external peril, the portrayal would also lend itself to another interpretation, which shows a hiatus between appearance and reality. Put in other words, the episode might present the image which was set out previously in the Life (4.4) - that of Artaxerxes being a virtuous ruler - as a mere façade ${ }^{35}$. This impression is stated more clearly in Cyrus' invective against his brother in the letter he sends to the Spartans (6.4) with the aim of obtaining their support in his effort to overthrow the king. Cyrus claims that because of his vices Artaxerxes is not able to hold his seat in a hunt or his throne in face of danger $^{36}$. What seems to be suggested in the chase scene is that the king is not able to keep in check his weaknesses - a shortcoming which is further stressed in the depiction of the leniency towards the Spartan or Tiribazus ${ }^{37}$ and pronounced in Cyrus' attack as $\delta \varepsilon \imath \lambda i ́ \alpha$ and $\mu \alpha \lambda \alpha \kappa i ́ \alpha$. Presumably, one reason for Artaxerxes' inability to restrain these passions is his unawareness of their existence within his soul $^{38}$. Nevertheless, these failings

34 A point underscored by a comparison of the description of the participants in the king's table (5.5), namely, his mother, wife and two brothers Ostanes and Oxathres, with the list of family members in the first chapter (1.2-4).

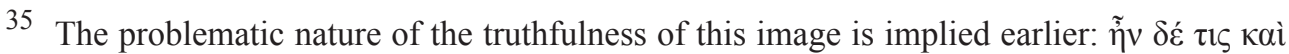

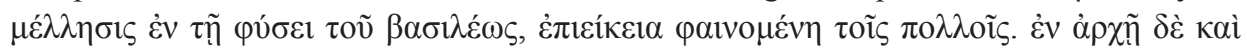

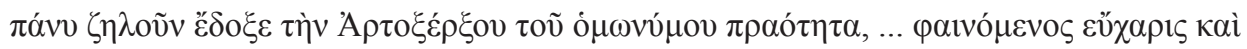

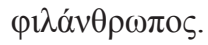

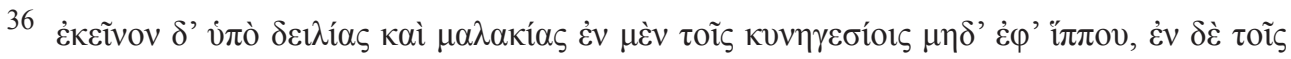

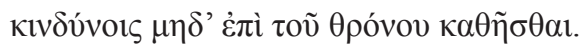

37 Note also the king's passive position in the hunt and his helplessness, when asking Tiribazus what he should do (5.3).

38 That Artaxerxes is unconscious of his failings is shown by the gap between his confident

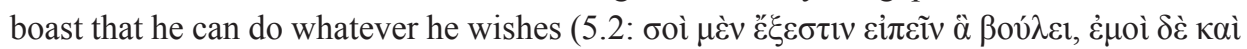

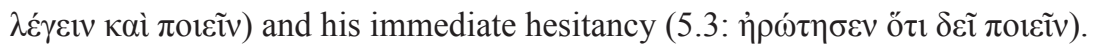


are as real as the beast that tore up his coat $^{39}$. In that respect, the absent animal seems to denote both an outward peril, i.e., Cyrus, and an inward one. Its nonappearance, thus, would seem to point at the need of Artaxerxes to face the challenge posed by his brother as well as to master his own emotions.

The tasks of filling up the gap created by the absent beast, guessing its identity as well as divining its symbolic and narratological importance, are left by Plutarch for the reader to perform ${ }^{40}$. The cooperation of the latter is needed in order to grasp the full implications of the scene. The reader, however, may easily overlook this point, and be as totally ignorant of the situation as Artaxerxes or else confounded by it, since a correct interpretation of this absence appears to be evasive. Seen through an EasternPersian prism, the lion's non-appearance may be interpreted as outright negative. The reader is to deduce that the absence of the lion, the most majestic of animals, perfectly suits the notion conveyed in the episode, namely, the corresponding absence of royal traits in the hero. On the other hand, bearing in mind Plato's use of the lion to represent the spirited part of the soul (Rep. 9.588de, 589b, 590d), a reading of the hunting passage in a Greek philosophical context would yield a wholly different understanding. It would either mean that the king succeeds in subduing the beast within himself or that he presents a mere disguise that covers up his basic inability to restrain passions - recalling Plato's censure against seeing only the outer shell of the human creature and not observing the animal lurking within (ib. 9.588e).

Ironically, the only lion ( $\left.\lambda \varepsilon^{\prime} \omega v\right)$ mentioned in the Life is the father of Antalcidas by that name $(21.6)^{41}$. It would seem that Plutarch toys with this name and its meaning on several levels. Despite being "a son of Leon", Antalcidas is no Leonidas. Not only is he not a king, but also, contrary to his Spartan forerunner, he does not hold out against the Persians in defence of Greek lands, but rather works to surrender the Hellenic cities in Asia Minor to the Great King. Unlike Antalcidas, and in a feat which appears to be the acme of his career, it is Artaxerxes who seems to be acting truly regal in enforcing his will on Greece. He is the one who appears to be the real lion, even though this association is obliquely presented in the text.

Indeed, Artaxerxes' coat is rent, which may indicate that the cover of appearance is shredded.

On reader response see Duff, 1999: 246; Pelling, 2002: 247-49.

41 A fact unattested in other sources. See SHIPLEY, 1997: 274-75, who tries to guess the identity of this Leon. Cf. Poralla, 1985: nos. 97, 482. Plutarch sometimes plays with

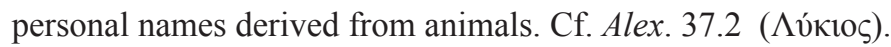


Furthermore, this lion is carefully balanced with another animal in the same chapter, hidden in an additional personal name, this time of a place, i.e., Aegospotami (21.1), literally "goat streams" 42 . Plutarch tells us that after the famous sea-battle fought there, Conon the Athenian commander fled to Cyprus where he found refuge ${ }^{43}$, immediately before he was employed in the service of Artaxerxes against the Spartans. In resemblance to the lion-Leonidas allusion, the mention of a goat might hark back at the Persian wars period, bringing to mind the assistance of Pan, the goatlike god, to the Athenians in the battle of Marathon (Hdt. 6.105.2-3) ${ }^{44}$. Just as Antalcidas disgraces the memory of his ancestors in the battle of Thermopylae by handing over the Greek cities to Persian control, so does Conon equally shame his own predecessors by assisting the very Persians who were previously their staunch enemies. Similar to the manner in which Leon (lion) is used to portray the king, the second beast (goat) may indicate another aspect of his character, an inert one, and definitely not majestic, as a creature led by others ${ }^{45}$. The tension between active and passive types of behaviour is recurrent throughout chapter $21^{46}$. Indeed, the association of Conon and Antalcidas, two men working for Artaxerxes, with animals, may indicate their active role as arousing the desires and appetites of a passive king.

The mention of lion and goat might also allude to Dionysiac epiphanies ${ }^{47}$. In some of the stories told of this god he is said to transform into these beasts,

42 Again, Plutarch occasionally plays on the meaning of the names of sites. For instance,

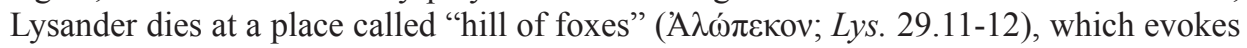
his self styled characterization as a fox (Lys. 7.6). Cf. DufF, 1999: 176, who takes it as a kind of retribution for his treacherous behaviour.

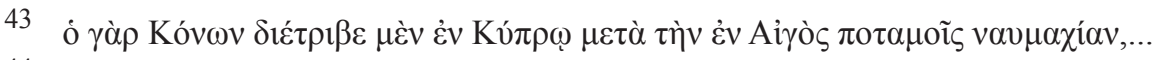

44 Pan is depicted as having the legs, horns, ears and tail of a goat. Cf. h.Pan. 2, 37; Plat. Crat. 408d; Nonn. D. 14.67 ff; cf. Ov. Fast., 4.751, 5.79 ff.; Met., 14.513 ff. Cf. Burkert, 1985: 172.

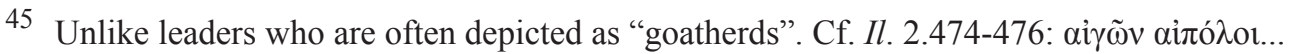

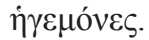

46 For instance, there are two versions explaining Ctesias' assignment to assist Conon (21.4). In the one he inserts this request into the letter of the Athenian commander, in order to influence the King, and in the other it is Artaxerxes who wishes it of his own accord, and

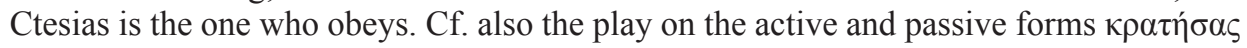
(21.5) and $\kappa \rho \alpha \eta \theta \varepsilon \tilde{\sigma} \sigma$ (21.6).

47 These two beasts were associated with him in different areas. Cf. Paus. 9.8.2, 10.18.6. Cf. Отто, 1965: 168-69, 176, 193; BurKert, 1985: 163, 233. Cf. his various appearances in the call of the faithful in Eur. Bacch. 1017-19. 
which were sacred to $\operatorname{him}^{48}$. There seems to be a great gulf between these two creatures, the one being a hunting beast and the other its obvious prey (cf. Il. 3.23-24) (9) $^{4}$ The self destructive aspect insinuated in the attribution of two antithetical beasts to the same deity may be transferred to Artaxerxes and characterize the king. Yet, the allusion to the contradictory guises of Dionysus as different animals may relate to the recurring theme of the variance between appearance and reality, and thus increase the general unclarity of the portrayal of Artaxerxes. The reader is uncertain whether the monarch's victory at sea and the "king's peace" were truly Artaxerxes' and present him as a leader, or were the achievements of others (Conon and Antalcidas) and only adopted by him $^{50}$. A related question is whether Artaxerxes underwent a real change, from a passive cowardly ruler (as he was in chapter 5) to a potent king. No less baffling is the question whether the vices previously attributed to him are unjustifiable accusations or inherent flaws skilfully hidden by Artaxerxes at present. The fact that the animals mentioned in this chapter are concealed within private names only enhances the perplexity.

The most intriguing link between the lion and the goat in the chapter would probably be the rôles of these two animals as constellations of the zodiac, i.e., $\lambda \varepsilon \dot{\varepsilon} \omega v$ (Leo), traditionally the fifth

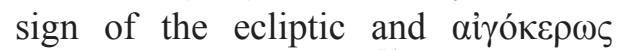
(Capricorn), the tenth ${ }^{51}$. The covert reference to the zodiac appears to be insinuating the temporality of the state

48 It is told that in order to escape Hera's wrath, and to protect him from the Titans, Zeus turns Dionysus into a harmless kid (Ps.-Apollod. 3.29-30). In another episode, when he is abducted by Tyrrhenian pirates, Dionysus transforms into a dreadful lion. Cf. h.Bacch., 7.44. On hints of Dionysiac presence in Plutarch's Lives cf. Pelling, 2002: 197-206.

Cf. Отто, 1965: 111: “... the animals that accompany Dionysus and in whose forms he himself appears, stand in sharp contrast to one another, with one group (bull, goat, ass) symbolizing fertility and sexual desire, and the other (lion, panther, lynx) representing the most bloodthirsty desire to kill".

Like the killing of Cyrus the Younger, an act done by others $(11.5,11.10)$, but appropriated by the king; cf. 14.5, 16.1.

51 See Vett.Val. 1.2. Note that the representation of the Capricorn was a mixture of a goat and a fish, derived from Mesopotamian concepts ( ${ }^{\mathrm{MUL} S U H U R . M A S}$ ) and iconography. (See Rochberg, 2004: 127-28, n. 21) - a hybrid that fits exactly the combination of

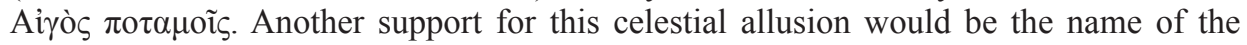
commander Conon, which might recall his famous $3^{\text {rd }}$ century BC namesake, the Samian mathematician and Ptolemaic court Astronomer (Prob. In Verg. Bucol. 3.40; Sen. Nat.

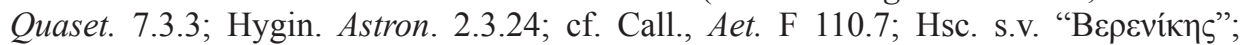
Tzetzes, De Pleiad. 550.23; cf. Catull. 66.7). On the popularity of the Zodiac in Roman times see GUNDEL, 1992. 
of affairs, and to a seasonal reversal in the fortune of states, cities ${ }^{52}$ and persons, a notion explicitly mentioned in chapter 21 in the image of the sea currents $^{53}$. This idea seems to suggest that the high point of Artaxerxes' career will also be temporary, subject to the rules of cyclic variation of chance. The period in which he may be seen as a kingly lion will be, therefore, shortlived. In addition, this allusion might point out that Artaxerxes shifts back and forth from passionate to restrained demeanour and from activity to passivity. Furthermore, one may suspect that Plutarch is activating another layer of meaning with regard to animals, that of horoscopic Astrology. While doing so, he appears to be making a tonguein-cheek concession to the popular contemporary beliefs, which match the position of the seven known planets relative to the twelve signs of the zodiac at birth or conception with a person's destiny and character ${ }^{54}$. Thus animals would reflect the characterization of the hero through their being symbols of constellations of stars and via the widely held conviction that these signs dictate types of personality. Applying the two signs of the lion and goat(horn) to Artaxerxes would imply a nature composed of two conflicting traits, or conversely - bearing in mind the notion of change, this might spell a character that undergoes some alteration in time.

A lion and a goat compose the monstrous beast known in Greek mythology as the Chimera (Xıнípa). This creature is said to be have the body and maned head of a lion, a goat head on its back and the tail of a serpent (or a dragon) ${ }^{55}$. While the third animal is admittedly missing from this chapter ${ }^{56}$, the presence of the other two might indicate that this beast is indeed alluded to. As used in Platonic psychology to symbolize the tripartite soul (Rep.9.588c), the implicit allusion to the Chimera may also suggest that Artaxerxes' personality

52 The chapter begins with the victory of Sparta at Aegospotami and ends with its virtual submission to the interests of Persia.

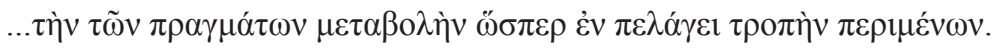

54 See, for instance, the belief in the effects of the signs on the size of a person's body: Ptol.

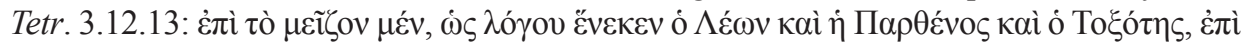

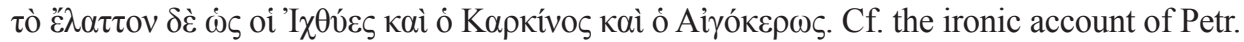
Satyr. 39. On ancient Astrology see Bouché-Leclerq, 1899; Cumont, 1912; Barton, 1994. On its popularity in the Roman period cf. Plut. Ant. 33.2, Rom. 12.3.

55 Hom. Il. 6.180; cf. Ov. Met. 9.646; Ps.-Apollod., 2.31-32; Ps.-Hygin. Fabul. 57, 151. Alternatively, it is described as having three heads of these aforementioned animals. See Hes., Th. 319 ff; cf. Ael., NA, 9.23.

56 Indeed, it is a detail often omitted altogether by Greek and Etruscan artists. See RoEs, 1934. 
is monstrously compiled out of two excluding features.

\section{Tyrants and Other Animals}

Unlike the previous allusions to the non-human living world, the last reference to animals in the Life is explicit. It draws some resemblances between the type of ruler Artaxeres is, or has become, and certain beasts. It is the closest Plutarch ever comes in the biography to a direct characterization of the hero as an anima ${ }^{57}$. Following his misfortune in the disastrous military campaign against the Cadusians (24.1-3), Artaxerxes leads his army into a paradeisos, a royal garden (25.1). After being depicted as caring for his soldiers and allowing them to cut the trees for wood (chopping down the first one to encourage them to follow suit), he is abruptly presented in a very different light. Now Artaxerxes is portrayed as killing many of his men out of anger and fear for his reputation, resulting from the failure of the expedition (25.3). Making an aside, the narrator illustrates tyrants in two situations, introducing the comparison by the particle $\gamma \alpha \dot{\alpha} \rho$. His claim is that when fear ( $\left.\dot{\eta} \delta \varepsilon \lambda \lambda^{i} \alpha\right)$ guides tyrants, it is lethal, but when they are occasionally led by their confidence ( $\left.\dot{\eta} \theta \alpha \rho \rho \alpha \lambda \varepsilon \tau^{\prime} \eta \varsigma\right)$, they are mild and unsuspicious. The connective word diò introduces another comparison, in which the narrator specifically likens tyrants to two classes of the genus "beasts"

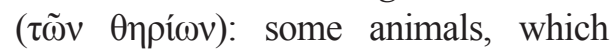
are intractable and hard to tame brutes

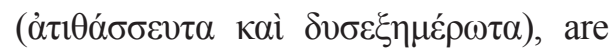
timid $(\delta \varepsilon 1 \lambda \dot{\alpha})$ and others, which are noble creatures ( $\gamma \varepsilon v v \alpha i \alpha)$, are confident because of their courage $(\theta \alpha \rho \rho \varepsilon \tilde{v})^{58}$. It would appear that by this association with animals the narrator aims to clarify the character of tyrants, and ultimately explain the murderous activities of the Persian king ${ }^{59}$.

Seemingly, this elucidation hits the mark. The reader would agree that Artaxerxes' manner now resembles that of a tyrant, and would intuitively bracket

57 Here the traditional portrayal of the leader as an animal - seen in the use of similes, e.g., that liken him to a lion (cf. Il. 3.23-26, 11.113-19, 172-78, 24.572) - is maintained, yet with an ironic twist, through an uncomplimentary association with tyrants. Cf. Moulton, 1977: 89ff. and LonSDALE, 1990: 50, 85 ff., 105-6, who see irony in the use of the lion simile already in Homer.

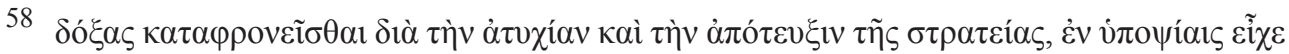

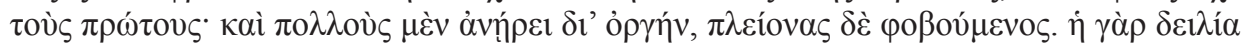

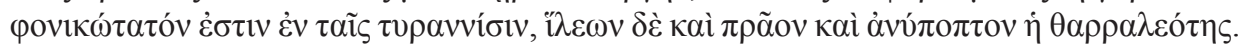

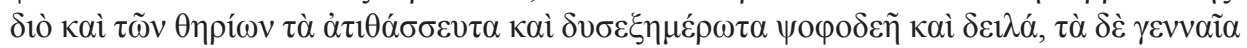

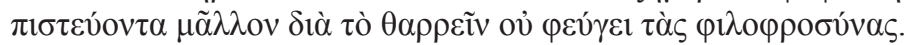

59

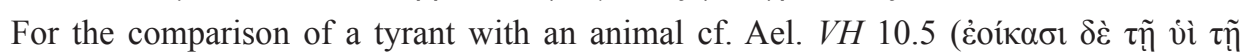

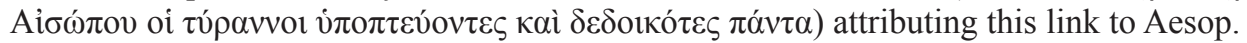
Cf. also Philo, Quod omnis probus liber sit, 89. 
him with the passionate unlawful ruler. Because of the monarch's brutality, the reader would also associate him with beasts ${ }^{60}$. Animals would thus appear to be characterizing the hero in a relatively straightforward way. Yet on a second, critical, reading of the Life, it would seem that viewing the passage as explicating the king's behaviour and directly mirroring the situation at hand is strained and has certain relatively superficial aspects. While the tyrant's fear may seem appropriate and indeed a commonplace ${ }^{61}$, the attribution of clemency and mildness to this kind of sovereign would appear to be out of place, and undeniably generates an awkward picture of a "virtuous tyrant" - almost a contradiction in terms ${ }^{62}$. Moreover, the narrator claims that animals which are hard to tame are timorous, yet this is not what we would naturally think. Untamed beasts usually tend to be wild and unrestrained ${ }^{63}$. Conversely, creatures that do not reject the friendly advances of humans do not necessarily show courage. Their conduct may reflect a broken spirit, the result of a long process of training. Hence, the reference to animals would seem almost as sudden as the abrupt behaviour of the king which they are supposed to explain.

Although it is Plutarch's opinion, as seen elsewhere, that the attribution of passions to beasts is real and not to be regarded as a metaphor ${ }^{64}$, the problematic presentation of the subject in the text of the Artaxerxes insinuates that the matter is not at all obvious. Of the passions assigned to animals in this

60 A possible unconscious influence on the reader would be passages such as those in the Platonic corpus highlighting the prominence of the monster within the composite soul of the tyrant (Rep. 9.588e). Cf. Phaedr. 248d: the tyrant is the last type of human life into which fallen souls are incarnated, just before beasts. The saying that the tyrant is the worst kind of animal appears in Plutarch, Sept. sap. conv. 147b; Quom. adul. 61c.

61 Cf. Soph. OT 583 ff.; Eur. Ion, 621-24; Hdt. 3.80; Plat. Rep. 9.578a-580a; Dio Chrys. Or. 3.59-60.

62 Cf. Soph. Ajax 1350. Plato regards tyranny as the embodiment of passions and the worst degradation: Rep. 9.562a-580c; cf. Gorg. 470d-472d; Polit. 302c-303b. The tyrant is more or less defined by his inability to trust others. It is true that in the Leg. (4.709d-712a) Plato lets the Athenian stranger propose a young and virtuous tyrant as the finest means for setting up the best constitution, yet this figure disappears from sight after this passage. See STALLEY, 1983: 91-92. It is the restrained horse of the Phaderus' chariot image that is seen by his wild partner as displaying $\delta \varepsilon \imath \lambda i ́ \alpha(254 \mathrm{c})$.

64 Cf. De sollert. 961d, 966b. Plutarch attacks the Stoics for only admitting emotions to

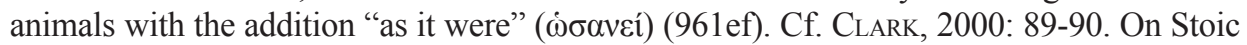
opinion see Newmyer, 2006: 28-29, Cf. Sorabji, 1993: 26, 58-61. Sen. De ira 1.3.4-5. 
passage one may be specifically applicable to beasts, namely $\psi 0 \varphi 0 \delta \varepsilon \tilde{\eta}^{65}$, while the other $\left(\delta \varepsilon \dot{\lambda} \alpha^{\prime}\right)$ is more typical of persons ${ }^{66}$. The course of the argument, therefore, involves the attribution of human features to animals as a clarification of the animal traits in humans. It thus runs the risk of falling into the fallacy of petitio principii, as the very ascription of these emotions to beasts seems to beg the question. Animals are brought in this passage in order to show the true bestial nature of the tyrant and of the king beneath a guise of moderation and feigned self-control. However, due to the artificiality lurking behind this chapter's presentation of animal traits, we start suspecting that the very practice of attributing particular passions to animals may be inappropriate ${ }^{67}$.

The puzzle only deepens with the awareness that the category of creatures which are difficult to tame

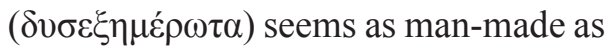
the composed (and unique) word that describes it. A correct interpretation of this concept is precluded by the inability to understand the true significance of its antonym, the trait of gentleness or being cultured ( $\dot{\varepsilon} \xi \eta \mu \varepsilon \rho \omega-)$. When applied to animals, Plutarch sometimes treats it as a natural feature ${ }^{68}$, and at times as entailing a harsh training ${ }^{69}$, namely, nurture. It would appear that the actual boundary between the realm of the natural, wild or untamed on the one hand, and the sphere of the unnatural and tamed on the other, is completely blurred. Even the presentation of the noble creatures ( $\gamma \varepsilon v v \alpha i \alpha)$ as naturally tamed (or tameable) obscures the distinctions between nature and nurture. The confusion is beautifully set against the initial image of chapter 25, depicting trees growing wild in the paradeisos, the garden of the king. Since they are living natural things that pre-suppose nurturing ${ }^{70}$, it is unclear what to make of these trees, and whether cutting them down would be acting contrary to nature or rather would mean removing an artificial obstacle in accordance with nature. Akin to his deed of

Cf. Quaest. conv. 642a, De sollert. 978e; cf. Camil. 27.3.

67 s.v. $\delta \varepsilon 1 \lambda o ́ \varsigma$ I. But cf. Hdt. 3.108, and n. 63 supra.

67 A serious problem in this attribution is whether a behaviour that would in humans be explained by a particular mental state necessitates the same state when similar conduct is observable in animals. Cf. NEwMYER, 2006: 36. The charge of an anthropomorphism may seem unavoidable. De sollert. 980e (crocodile).

69 Brut. anim. rat. $987 \mathrm{f}$ (whelps); Quaest. conv. 7.703e (dogs).

70 The paradeisos is found in a region which is bare and treeless (25.1: $\dot{\varepsilon} v \tau \tilde{\varphi} \pi \dot{\varepsilon} \rho 1 \xi \dot{\alpha} \delta \varepsilon \dot{\varepsilon} \delta \rho \emptyset$

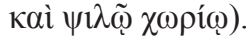


chopping a tree, Artaxerxes' killing of his men may equally point at two options: either some natural passion is finally exposed, casting aside an unreal pretence of restraint, or else the act done is contrary to his moderate nature, marking a real transformation in his character. Though clearly presented as such by the narrator, the characterization of the hero through animals does not work here in a clearcut manner, but in a very slippery mode. The introduction of unnatural natural beasts, as it were, which display both traits of restraint and unruliness, only leads one to seriously question the possibility of ever grasping the right association of the king and the animals, or of attaining a true understanding of Artaxerxes' ethos. The reader may doubt whether the explicit link to beasts made by the narrator is superficial or not, and whether it assists in revealing a bestial aspect in the hero or rather, by adjoining human traits with other living creatures, it brings about a change in nature - of animals and the hero alike.

\section{Conclusion}

Characterized by an inner psychological struggle, the soul of Artaxerxes is not portrayed in a consistent or clear manner. Plutarch's descriptions are elusive, and often put across a variety of possibilities to interpret a scene. Animal imagery serves this ambiguity. Beginning with an episode in which a lion is conspicuously missing and finishing off with a literary comparison of tyrants with beasts, Plutarch does not let any animal in this Life openly depict Artaxerxes as regal, but rather makes all the creatures point at the complex makeup of the protagonist's psyche. Plutarch's beasts are thus burdened with narratological significance: the absent or the hidden creatures indicate invisible narrative layers in the work, while the animals that are introduced in a superficial metaphor or a problematic comparison betray the unreliability of the overt elements provided to the reader. This role of animals perhaps arises from their dual character in the composition, both as taking part in the action of the story themselves and as having an obvious symbolic dimension. Correspondingly, beasts are most successful in conveying the sense of two layers existing in the bioigraphy: the plain yet colorful narrative sequence of the Life, and the other, different, inner meaning, which has a life of its own. It is a reality often parallel to the main narrative, but sometimes clashing with it. Hence beasts are not only employed to embellish or enliven the Lives, but, due to the soul, which they share with the hero, animals should be considered the spirit that truly animates the text.

\section{BibliograPHY}

Albenda, P.,

- 'Ashurnasirpal II Lion Hunt Relief BM 124534', JNES, 31 (1972), 167-78

Almagor, E.,

- "A 'Barbarian' Symposium and the Absence of Philanthropia (Artaxerxes 15)", 
in J. R. Ferreira, D. F. LeÂo, M. Töster \& P. B. Dias (eds.), Symposion and Philanthropia in Plutarch, Coimbra, Classica Digitalia/Centro de Estudos Clássicos e Humanísticos, 2009, 131-146.

Ash, R.,

- "Severed Heads: Individual Portraits and Irrational Forces in Plutarch's Galba and Otho" in J. M. Mossman (ed.) Plutarch and his Intellectual World, London, 1997, 189-214.

BABUT, D.,

- Plutarque et le Stoïcisme, Paris, 1969.

BARTON, T. S.,

- Ancient Astrology, London \& New York, 1994.

Bouché-LeClercQ, A.

- L'astrologie grecque, Paris, 1899.

Boulogne, J. (ed.)

- Les Grecs de l'antiquité et les animaux. Le Cas remarquable de Plutarque, Lille, 2005.

BRENK, F.E.,

- In Mist Apparelled: Religious Themes in Plutarch's "Moralia" and "Lives", Leiden, 1977.

- "From Rex to Rana: Plutarch's Treatment of Nero", in A. CERASAGastaldo (ed.), Il Protagonismo nella Storiografia Classica, Pubblicazioni del Dipartimento di Archeologia, Filologia Classica e Loro Tradizioni, Genova, 1987, 121-142.

BRIANT, P.,

- "Chasses Royales Macédoniennes et Chasses Royales Perses: le thème de la Chasse au lion sur la Chasse de Vergina" DHA 17 (1991), 211-255.

- From Cyrus to Alexander, Winona Lake, IN, 2002 (an English translation of Histoire de l'Empire Perse: De Cyrus à Alexandre, Paris, 1996).

BUCHER-ISLER, B.,

- Norm und Individualität in den Biogra- phien Plutarchs, Bern \& Stuttgart, 1972.

Burkert, W. ,

- Greek Religion. (Trans. J. Raffan), Cambridge, MA, 1985.

Clark, G.,

- “Animal Passions", $G \& R, 47: 2000$, pp. 88-93.

Cumont, F.,

- Astrology and Religion among the Greeks and Romans, New York ,1912.

De LaCy, P. H.

- "Biography and Tragedy in Plutarch" AJPh 73 (1952): 159-171.

Detienne, M.,

- "Between beasts and gods" in R.L. Gordon (ed.), Myth, religion and society, Cambridge, 1981, 215-28, 270-71.

Dillon, J.,

- The Middle Platonists, London, 1977.

DuFf, T.,

- Plutarch's Lives: Exploring Virtue and Vice, Oxford, 1999.

FERrari, G.R.F.,

- "The Three-Part Soul" in id. (ed.), The Cambridge Companion to Plato's Republic, Cambridge, 2007, 165-201.

Flacelière, R. and Chambry, E.,

- Plutarque, Vies, tome xv, Paris, 1979.

FuHRMAnN, F.

- Les images de Plutarque, Paris, 1964.

GERSON, L.P.,

- Knowing Persons: A Study in Plato, Oxford, 2003.

Gilhus, I. S.,

- Animals, Gods, and Humans: Changing Attitudes to Animals in Greek, Roman, and Early Christian Thought, New York: Routledge, 2006.

GiLl, C.,

- The Structured Self in Hellenistic and Roman Thought, Oxford \& New York, 2006. 
Griswold, C. L.,

- Self-Knowledge in Plato's Phaedrus, New Haven: Yale, 1986.

Gundel, H.G.,

- Zodiakos. Tierbilder im Altertum, Mainz am Rhein, 1992.

HACKFORTH, R.,

- Plato's Phaedrus, Cambridge, 1952.

Hall, E.,

- Inventing the Barbarian, Oxford, 1989.

IsAAC, B.,

- The Invention of Racism in Classical Antiquity, Princeton and Oxford: Princeton University Press, 2004.

JoNES, R.M.,

- The Platonism of Plutarch, Menasha, Wisconsin, 1916.

Ju, A. E.,

- "Chrysippus on Nature and Soul in Animals", CQ 57 (2007), 97-108.

Lonsdale, S. H.,

- Creatures of speech. Lion, herding, and hunting similes in the Iliad, Stuttgart, 1990.

LORENZ, H.,

- The Brute Within: Appetitive Desire in Plato and Aristotle, Oxford, 2006.

- "Plato on the Soul" In G. Fine (ed.) The Oxford Handbook of Plato, Oxford, 2008, 243-266.

Manfredini, M., Orsi, D.P \& Antelami, I.,

- Plutarco., Le Vite di Arato et di Artaserse, Rome, 1987.

Marasco, G.,

- Plutarco. Vita : volume quinto : Demetrio e Antonio - Pirro e Mario - Arato - Artaserse, Agide - Clemone e TiberioGaio Gracco, Torino, 1994.

Miller, F.D.,

- "Plato on the Parts of the Soul" in N. D. Smith (ed.) Plato: Critical Assessments, vol. 3, London, 48-65.
Mossman, J. M.,

- "Tragedy and Epic in Plutarch's Alexander", JHS 108 (1988), 83-93.

Moulton, C.,

- Similes in the Homeric Poems, Göttingen 1977.

Newmyer, S. T.,

- "Speaking of Beasts: The Stoics and Plutarch on Animal Reason and the Modern Case against Animals." QUCC N.S. 63 (1999), 99-110.

- Animals, Rights and Reason in Plutarch and Modern Ethics, New York: Routledge, 2006.

NipPEL, W.,

- "The construction of the "Other"" (trans. A. Nevill), in T. Harrison (ed.), Greeks and Barbarians, New York, 2002, 278-310.

Osborne, C.,

- Dumb Beasts and Dead Philosophers: Humanity and the Humane in Ancient Philosophy and Literature, Oxford, 2007.

OSTENFELD, E.N.,

- "Self-Motion, Tripartition, and Embodiment", in: L. Rossetti (Ed.), Understanding the "Phaedrus". Proceedings of the II. Symposium Platonicum, St. Augustin, 1992, 324-28.

Oтто, W.F.,

- Dionysus: Myth and Cult (trans. R. B. PALMER), Bloomington, 1965.

Pelling, C.

- "Plutarch's Method of Work in the Roman Lives" JHS, 99 (1979), 74-96.

- "Plutarch's Adaptation of his SourceMaterial" JHS, 100 (1980) 127-140.

- Plutarch: Life of Antony, Cambridge, 1988.

- Plutarch and History, London, 2002.

Poralla, P.,

- Prosopographie der Lakedaimonier (1913) second ed. by A.S. Bradford Chicago: Ares, 1985. 
Rees, D.A.,

- "Bipartition of the Soul in the Early Academy", JHS 77 (1957), 112-118.

Rochberg, F.,

- The Heavenly Writing. Divination, Horoscopy, and Astronomy in Mesopotamian Culture, Cambridgee, 2004.

Roes, A.,

- "The Representation of the Chimaera," JHS 54 (1934): 21-25.

Russell, D.A.,

- “On Reading Plutach's Lives", $G \& R$, 13 (1966) 139-154.

SAID, S.,

- "Plutarch and the People in the Parallel Lives", in L. De Blois, J. Bons, T. Kessels, D. M. Schenkeveld, The Statesman in Plutarch's Works. Volume I: Plutarch's Statesman and His Aftermath: Political, Philosophical, and Literary Aspects, Leiden: Brill, 2004, 7-25.

SChmidT, T. S.,

- Plutarque et les Barbares: la rhétorique d'une image, Louvain, 1999.

SHIPLEY, D.R.,

- A Commentary on Plutarch's Life of Agesilaos, Oxford, 1997.

SORABJI, R.,

- Animal Minds and Human Morals: The Origins of the Western Debate, Ithaca, NY: Cornell University Press, 1993.

STADTER, P.

- "Anecdotes and the Thematic Structure of Plutarchean Biography," in J.A. FERNÁNdeZ Delgado and F. Pordomingo PARDo (eds.), Estudios sobre Plutarco, IV. Aspectos formales, Madrid, 1996, 291-303.
STALley, R.F.

- An Introduction to Plato's Laws, Oxford, 1983.

SteIner, G.,

- Anthropocentrism and Its Discontents, the Moral Status of Animals in the History of Western Philosophy, Pittsburgh: University of Pittsburgh Press, 2005.

SwAIN, S.,

- "Character Change in Plutarch" Phoenix 43 (1989), 62-68.

TRAPP, M. B.,

- "Plato's Phaedrus in second-century Greek literature" in D. A. Russell (ed.) Antonine Literature, Oxford, 1990 141-73.

VAnder Waerdt, P. A.,

- "Peripatetic Soul-Division, Posidonius and Middle Platonic Moral Psychology," GRBS 26 (1985) 373-94.

- “Aristotle's Criticism of Soul-Division”, AJPh, 108 (1987), 627-643.

Vernant, J.-P.,

- "Between the beasts and the gods", in: Id., Myth and Society in Ancient Greece, New York 1980, 143-182.

WhitMARsh, T.,

- “Alexander's Hellenism and Plutarch's textualism”. CQ, 52 (2002), 174-192.

Wiedemann, T.,

- "Between man and beasts: barbarians in Ammianus Marcellinus" in I.S. Moxon, J.D. Smart \& A.J. Woodman (eds.), Past Perspectives, Cambridge, 1986, 189-211.

ZAdOROJNYI, A.V.,

- "Plutarch's Themistocles and the Poets" AJPh, 127 (2006), 261-292. 